\title{
Subcritical crack growth in rocks in an aqueous environment ${ }^{*}$
}

\author{
Yoshitaka Nara ${ }^{1,3}$ Masafumi Takada ${ }^{2}$ Toshifumi Igarashi $^{1}$ Naoki Hiroyoshi $^{1}$ \\ Katsuhiko Kaneko ${ }^{1}$ \\ ${ }^{1}$ Graduate School of Engineering, Hokkaido University, Kita 13 Nishi 8, Kita-ku, Sapporo, \\ Hokkaido 060-8628, Japan. \\ ${ }^{2} J G C$ Corporation, 2-3-1, Minato Mirai, Nishi-ku, Yokohama, Kanagawa 220-6001, Japan. \\ ${ }^{3}$ Corresponding author. Email: nara@geo-er.eng.hokudai.ac.jp
}

\begin{abstract}
Subcritical crack growth is one of the main causes of time-dependent fracturing in rock. In the present study, we investigated subcritical crack growth in rock in distilled water $(\mathrm{pH}=5-7)$ and in an aqueous solution of sodium hydroxide ( $\mathrm{NaOHaq}, \mathrm{pH}=12)$, comparing the results to those in air. We also investigated the effect of the $\mathrm{pH}$ in an aqueous environment. We used andesite and granite for all our tests. We determined the relationship between the crack velocity and the stress intensity factor using the double-torsion test under conditions of controlled temperature. We showed that crack velocities in water were higher than those in air, in agreement with other research results indicating that crack velocity increases in water. When we compared our results for $\mathrm{NaOHaq}$ with those for water, however, we found that the crack velocity at the same stress intensity factor did not change even though the $\mathrm{pH}$ of the surrounding environment was different. This result does not agree with the accepted understanding that hydroxide ions accelerate subcritical crack growth in rocks. We concluded that the $\mathrm{pH}$ at the crack tip influences subcritical crack growth, and not the bulk $\mathrm{pH}$, which has little effect.
\end{abstract}

Key words: aqueous environment, double-torsion test, rock, subcritical crack growth, temperature.

\section{Introduction}

Understanding the time-dependent fracturing behaviour of rock is essential to ensure the long-term stability of structures in a rock mass such as underground power plants or caverns for storing liquefied petroleum or natural gas. Cracks have been postulated to propagate dynamically when the stress intensity factor reaches the fracture toughness in classical fracture mechanics. However, a crack can propagate slowly even when the stress intensity factor is less than the fracture toughness. This phenomenon, called subcritical crack growth (Atkinson, 1984), is one of the main causes of time-dependent change in rocks. Because subcritical crack growth appears to be affected by the surrounding environment (Anderson and Grew, 1977), it is important to investigate the effects of environmental conditions.

The crack velocity in rocks, which clearly increases when the atmospheric water vapour pressure is high (Nara and Kaneko, 2005,2006 ), is anisotropic due to the preferred orientation of preexisting microcracks in granite (Nara and Kaneko, 2006; Nara et al., 2006). Based on the concept of subcritical crack growth, Jeong et al. (2007) reported that the strength of rock decreased when the water vapour pressure of the surrounding environment was high. In actual environments of rock engineering or underground excavation, the rock is often wet. Therefore, it is essential to investigate the subcritical crack growth in rocks in aqueous environments to have a better understanding of the timedependent fracturing behaviour of rock.

In the present study, we investigated subcritical crack growth in rocks in an aqueous environment using distilled water $(\mathrm{pH}=5-7)$ and $\mathrm{NaOHaq}(\mathrm{pH}=12)$. We focused on the effects of temperature, water, and $\mathrm{pH}$ on subcritical crack growth in andesite and granite.

\section{Crack velocity for subcritical crack growth}

The subcritical crack growth in silicate materials appears to be controlled by the chemical reaction between the siloxane bond and a corrosive agent at the crack tip under tension (Anderson and Grew, 1977; Atkinson, 1984). This reaction is called stress corrosion, and the corrosive agents that have been studied include water (Michalske and Freiman, 1982) and the hydroxide ion (Charles, 1958).

The crack velocity $\mathrm{d} a / \mathrm{d} t$ can be related to the stress intensity factor $K_{\mathrm{I}}$ by the following empirical equation (Wiederhorn and Bolz, 1970; Freiman, 1984):

$$
\frac{\mathrm{d} a}{\mathrm{~d} t}=v_{0} a_{c} \exp \left(\frac{-E_{\mathrm{a}}+\beta K_{\mathrm{I}}}{R T}\right),
$$

where $a_{c}$ is the activity of the corrosive agent, $E_{\mathrm{a}}$ is the stress-free activation energy, $R$ is the gas constant, $T$ is the absolute temperature and $v_{0}$ and $\beta$ are constants (Freiman, 1984).

\section{Methodology \\ Experimental method}

In the current study, we used the double-torsion (DT) loadrelaxation test (Williams and Evans, 1973; Sano and Kudo, 1992). Figure 1 shows a schematic illustration of the specimen and the loading configuration. As shown in this figure, the specimen is a rectangular plate that often includes a guide groove to control the path of the crack propagation in the central part of the specimen. In Figure 1, four thick arrows show the loading forces, which are applied at the end of the specimen. Because the stress intensity factor is independent of the crack length, the DT test is convenient for opaque materials such

\footnotetext{
*Presented at the 19th ASEG Geophysical Conference \& Exhibition, November 2007.
} 


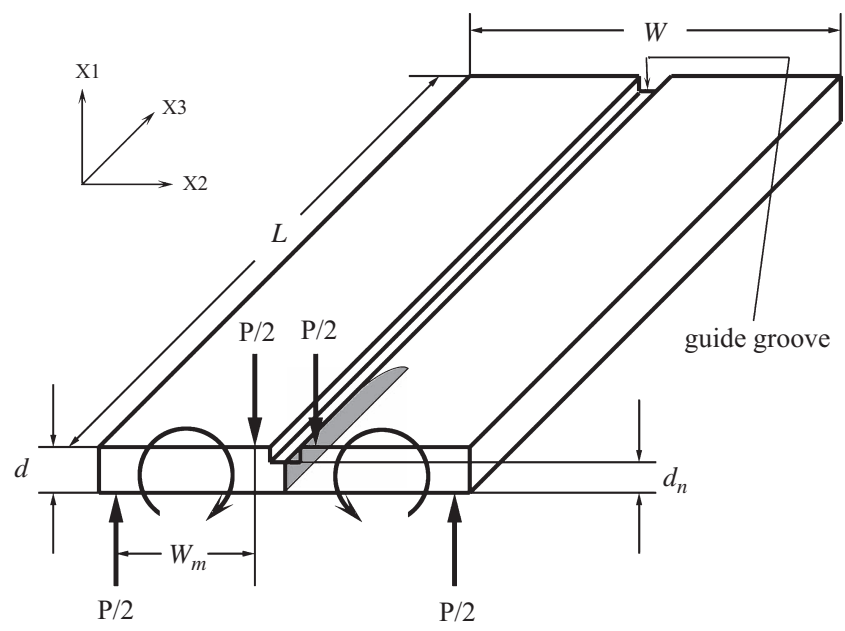

Fig. 1. Double-torsion specimen and loading configuration. Four thick arrows show the loading forces.

as rocks in which the exact measurement of the crack length is difficult. For this reason, the DT test was used in this study.

For isotropic materials, the stress intensity factor and the crack velocity can be estimated by the following equations (Williams and Evans, 1973):

$$
\left.\begin{array}{c}
K_{\mathrm{I}}=P w_{m} \sqrt{\frac{3(1+v)}{W d^{3} d_{n}},} \\
\frac{\mathrm{d} a}{\mathrm{~d} t}=-0.2 \times \frac{S_{0} P_{0}}{B P^{2}} \frac{\mathrm{d} P}{\mathrm{~d} t} \\
B=\frac{3 w_{m}^{2}}{W d^{3} G}
\end{array}\right\},
$$

where $P$ is the applied load, $w_{m}$ is the moment arm, $v$ is Poisson's Ratio, $W$ is the width of the specimen, $d$ is the thickness of the specimen, $d_{n}$ is the reduced thickness of the specimen, $P_{0}$ is the initial value of the applied load, $S_{0}$ is the compliance of the specimen at the initial crack length $a_{0}, \mathrm{~d} P / \mathrm{d} t$ is the load relaxation rate, and $G$ is the shear modulus.

For orthorhombic materials, assuming that the directions of the coordinate axes and loading are defined as shown in Figure 1, the stress intensity factor and the crack velocity can be estimated by the following equations (Sano and Kudo, 1992):

$$
\begin{gathered}
K_{\mathrm{I}}=\left(\frac{3 P^{2} w_{m} s_{44}}{2 d^{3} d_{n}\left(2 s_{22}\left(\left(s_{33} s_{22}\right)^{1 / 2}+s_{32}+s_{44} / 2\right)\right)^{1 / 2}}\right)^{1 / 2}, \\
\frac{\mathrm{d} a}{\mathrm{~d} t}=0.2 \times \frac{-2 S_{0} P_{0}(\mathrm{~d} P / \mathrm{d} t) d^{3}}{3 P^{2} s_{44} w_{m}},
\end{gathered}
$$

where $s_{\mathrm{ij}}(\mathrm{i}, \mathrm{j}=1-6)$ is the compliance constant of the material. If the loading direction is different from that shown in Figure 1, the subscripts of $s_{\mathrm{ij}}$ in equations (4) and (5) must be switched.

For our experiments, the width $(W)$ was $45 \mathrm{~mm}$, the length $(L)$ was $140-200 \mathrm{~mm}$, the thickness $(d)$ was $3 \mathrm{~mm}$ and the reduced thickness $\left(d_{n}\right)$ was $2 \mathrm{~mm}$. For a DT specimen, a guide groove is often cut in the specimen to make the crack propagate in the central part of the specimen as shown in Figure 1. Nara (2004) reported that crack propagation was not controlled by the guide groove if the width of the groove was less than the mean grain size of the rock. Therefore, the width of the guide groove in these experiments was $1 \mathrm{~mm}$ for granite, because the mean grain size of granite used in the present study was $\sim 1 \mathrm{~mm}$. The width of the guide groove for andesite was $2 \mathrm{~mm}$, because the size of some phenocrysts was larger than $1 \mathrm{~mm}$. The guide groove was set upward according to the method of Pletka et al. (1979) as shown in Figure 1.

\section{Rock samples}

The rock samples used for our DT tests were Kumamoto andesite and Oshima granite, quarried in Japan.

We measured the P-wave velocities in three orthogonal directions using the ultrasonic transmission method. The P-wave velocities of the Kumamoto andesite were 4.80, 4.80, and $4.83 \mathrm{~km} / \mathrm{s}$. Therefore, this rock was considered isotropic, and we used equations (2) and (3) to estimate its stress intensity factor and crack velocity.

Young's Modulus and the Poisson's Ratio were determined with a uniaxial compression test on cylindrical specimens using a strain rate of $10^{-6} \mathrm{~s}^{-1}$. The diameter and length of the specimens were $35 \mathrm{~mm}$ and $70 \mathrm{~mm}$, respectively. We determined the uniaxial strength to be $151 \mathrm{MPa}$. Young's Modulus and the Poisson's Ratio determined from the tangential line of the stress-strain curve at the $50 \%$ uniaxial strength point were $31.9 \mathrm{GPa}$ and 0.27 , respectively. Therefore, the shear modulus was $12.6 \mathrm{GPa}$.

Granite, however, has been described as being anisotropic, and Sano et al. (1992) and Peacock et al. (1994) both reported that Oshima granite exhibited P-wave velocity anisotropy. Additionally, Sano et al. (1992) stated that the granite had orthorhombic elasticity due to the preferred orientation of pre-existing microcracks. For this study, we measured the P-wave velocities of Oshima granite in three orthogonal directions, and the results of $4.91,4.61$, and $4.51 \mathrm{~km} / \mathrm{s}$ confirmed that Oshima granite is indeed anisotropic. We defined the orthogonal directions we used as axis-1, axis-2, and axis-3 in the order of the measured P-wave velocities. The planes normal to these three axes are plane-1, plane-2, and plane-3, and are consistent with the Hardway, Grain, and Rift planes, respectively (Kudo et al., 1987).

In the preparation of our DT granite specimens, it was necessary to consider the crack opening direction and crack propagation direction, because of the orthorhombic elasticity generally observed in granite. Figure 2 shows the possible orientation of our granite specimens. In the current study we used the $3 \cdot 2$-specimen, in which the crack propagates parallel to axis-3 and opens parallel to axis-2.

We used equations (4) and (5) to estimate the stress intensity factor and the crack velocity in granite. The values of the compliance constants $s_{\mathrm{ij}}$ were determined by Nara and Kaneko (2006). Parameters $s_{22}, s_{33}, s_{44}$ and $s_{32}$ in equations (4) and (5) were $18.9,19.7,46.0$, and $-3.28\left[10^{-12} \mathrm{~Pa}^{-1}\right]$, respectively.

We kept our rock specimens in distilled water or $\mathrm{NaOHaq}$ for more than 2 weeks before conducting our DT tests.

\section{Experimental apparatus}

Figures $3 a$ and $3 b$ show the DT testing apparatus used for our experiments with water and $\mathrm{NaOHaq}$, respectively. The apparatus was located in a room in which the temperature and the relative humidity could be controlled in the ranges $278-353 \mathrm{~K}$ and $40-90 \%$, respectively. The apparatus was the same as that used by Nara and Kaneko (2005) except for the stainless steel tank in Figure $3 a$ and the stainless steel plate at the bottom of the polymethyl methacrylate tank in Figure $3 b$. In all experiments, the 


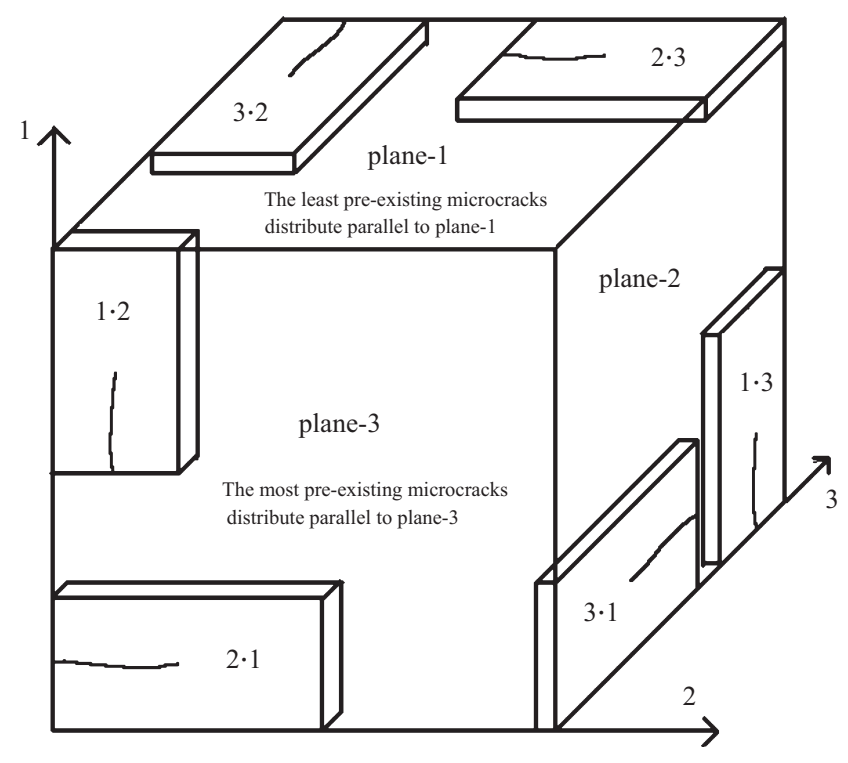

Fig. 2. Schematic view of specimen orientations for Oshima granite. The smallest and greatest numbers of pre-existing microcracks are distributed parallel to plane-1 and plane-3, respectively.
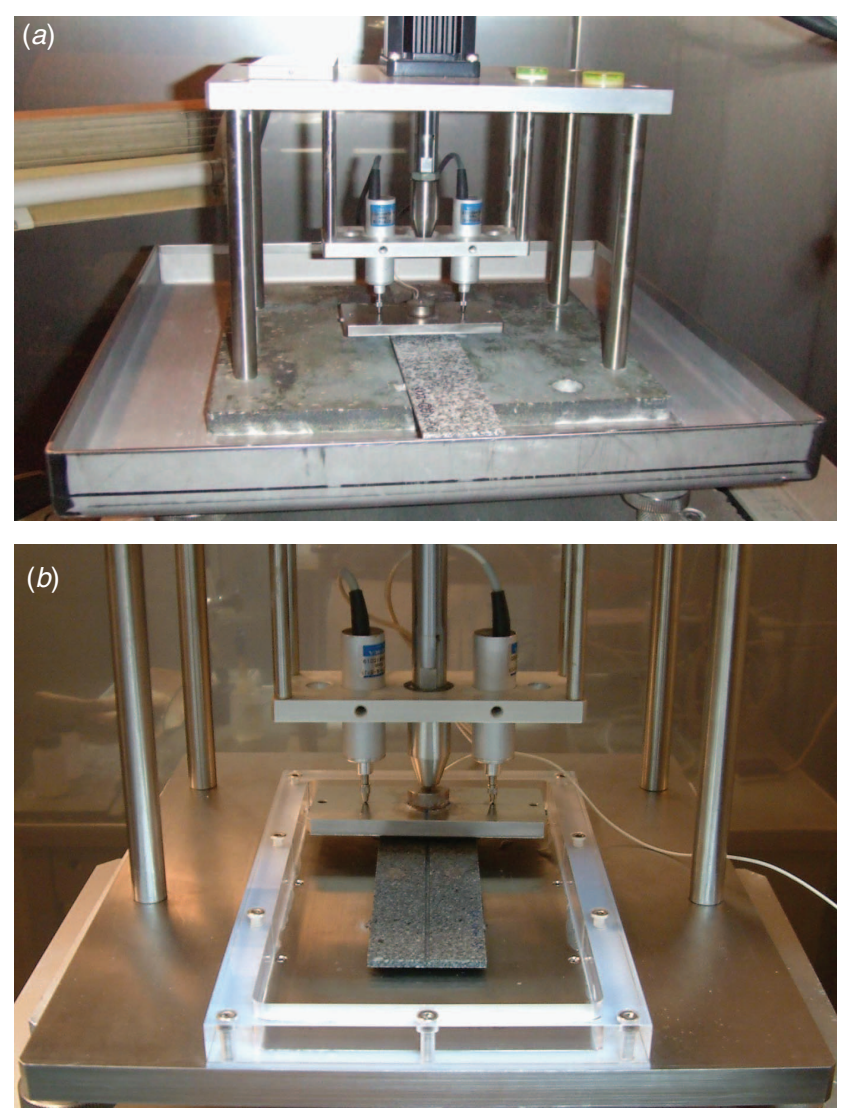

Fig. 3. Double-torsion testing apparatus used for the experiment in aqueous environments: $(a)$ water and $(b) \mathrm{NaOHaq}$.

temperature in the aqueous environment was kept constant by controlling the air temperature.

\section{Experimental procedure}

First, we performed specimen precracking with the apparatus used by Nara and Kaneko (2005), because it was possible to observe the crack introduced by this procedure with a digital microscope mounted under the DT specimen as shown in Figure 4. We used the technique described by Pletka et al. (1979). The load was applied slowly to the specimen, occasionally adjusting the displacement of the loading points, while observing the crack introduced in this procedure. We rapidly decreased the load when we recognised that the crack length reached $25 \mathrm{~mm}$, to satisfy the condition shown by Trantina (1977). According to Trantina (1977), $K_{\mathrm{I}}$ is independent of the crack length when the crack length satisfies the condition:

$$
0.55 W<a<L-0.65 \text {. }
$$

Because the width $W$ in this study is $45 \mathrm{~mm}$, the above condition is satisfied when the crack length exceeds $25 \mathrm{~mm}$.

After precracking, we held the temperature of the testing room constant. The rock specimens were exposed to the testing environment for $20 \mathrm{~h}$ before we conducted the DT loadrelaxation tests.

We conducted our DT tests under the same loading conditions for each rock type. First, we slowly applied a preload of 12-15 N, which corresponded to $15-25 \%$ of the maximum load. Then we applied a large displacement rapidly to the loading points of the specimen and held it constant throughout the measurement. This large displacement was $0.27 \mathrm{~mm}$ for Kumamoto andesite and $0.24 \mathrm{~mm}$ for Oshima granite, as specified by Nara and Kaneko $(2005,2006)$. In the DT load-relaxation test, the temporal change of the applied load is measured to evaluate the crack velocity and the stress intensity factor. The temporal changes of the applied load obtained by the above procedure are shown in Figure 5. Although the data of $0-300 \mathrm{~s}$ is shown in this figure, each DT load-relaxation test was carried out for $1.5-2 \mathrm{~h}$.

\section{Results}

Before actually testing rocks, we conducted DT tests on soda-lime glass in distilled water to investigate the reproducibility of the results. Figure 6 shows the relationship between the stress intensity factor and the crack velocity ( $K_{\mathrm{I}}-\mathrm{d} a / \mathrm{d} t$ relationship) for soda-lime glass. Open and solid symbols indicate the $K_{\mathrm{I}}-\mathrm{d} a / \mathrm{d} t$ relationships obtained from the apparatus shown in Figures $3 a$ and $3 b$, respectively. The mean value of the measured bulk pH was 6 . Figure 6 shows that the reproducibility of the results was high. Additionally, the $K_{\mathrm{I}}-\mathrm{d} a / \mathrm{d} t$ relationships agreed closely with each other even when the testing apparatus was different. Therefore, we concluded that the DT test setups worked well, and that the experimental procedure in this study was appropriate.

After the preliminary tests on soda-lime glass, we performed the DT tests on rock. To investigate the effect of the temperature, we conducted these tests in distilled water at different temperatures for Kumamoto andesite. The mean value of the measured bulk pH was 5 for high temperature (328 K) DT tests and 7 for low temperature $(285 \mathrm{~K})$ tests. Figure 7 shows the $K_{\mathrm{I}}-\mathrm{d} a / \mathrm{d} t$ relationships for Kumamoto andesite, and illustrates that the crack velocity at the same stress intensity factor is higher when the temperature is higher. The same tendency was observed for Inada granite and Shirahama sandstone by Kodama et al. (2003). Thus, the temperature appears to affect the subcritical crack growth of rock in water.

Figure 8 shows the $K_{\mathrm{I}}-\mathrm{d} a / \mathrm{d} t$ relationships in water to compare with the results in air for Kumamoto andesite reported by Nara and Kaneko (2005); the crack velocity at the same stress intensity factor is clearly much higher in water. The same tendency exists for Oshima granite as shown in Figure 9. Water undoubtedly has a strong effect on the subcritical crack growth in rocks.

To investigate the effect of the $\mathrm{pH}$ in an aqueous environment, we measured the crack velocity and the stress intensity factor in 

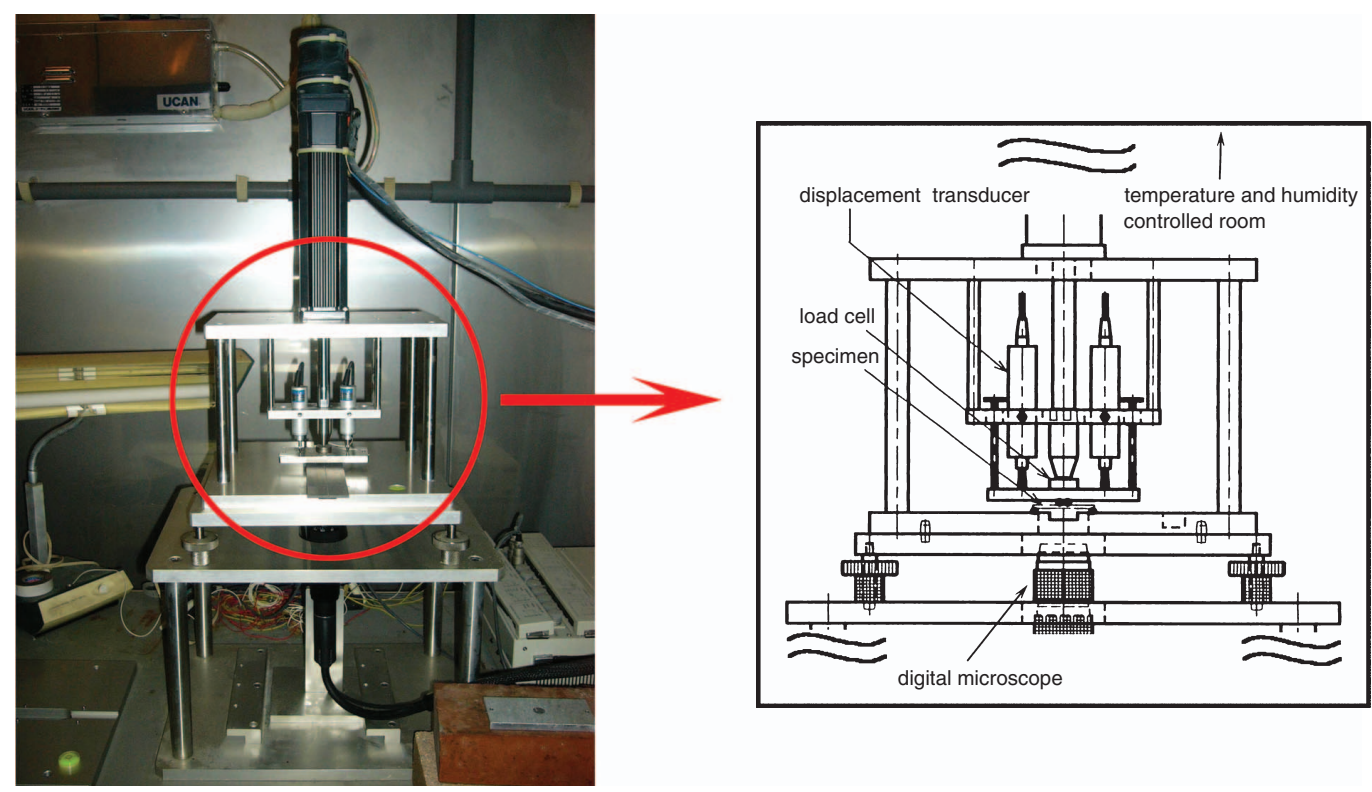

Fig. 4. Double-torsion testing apparatus used in the precracking procedure.

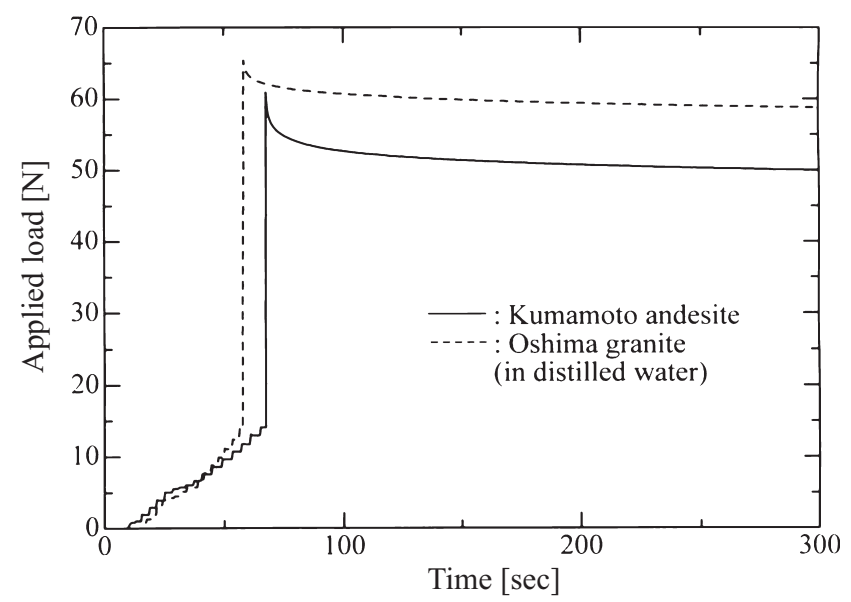

Fig. 5. The temporal changes of the applied load for andesite and granite obtained in distilled water.

$\mathrm{NaOHaq}$. The mean value of the measured bulk $\mathrm{pH}$ was 12 . The $K_{\mathrm{I}}-\mathrm{d} a / \mathrm{d} t$ relationships in $\mathrm{NaOHaq}$ for Kumamoto andesite and Oshima granite are shown in Figures 10 and 11, respectively. These figures also indicate the $K_{\mathrm{I}}-\mathrm{d} a / \mathrm{d} t$ relationships in distilled water for the sake of comparison. Distinct differences cannot be observed in the $K_{\Gamma}-\mathrm{d} a / \mathrm{d} t$ relationships even for the different values of bulk $\mathrm{pH}$. This result does not agree with the accepted understanding that hydroxide ions accelerate subcritical crack growth in silicate materials (Atkinson and Meredith, 1981). No accounts of this tendency have been reported in rocks.

Tables 1 and 2 show the results obtained by applying equation (1) to the experimental data for Kumamoto andesite and Oshima granite, respectively. In these tables, $\alpha$ can be expressed by the following equation, which was obtained by rearranging equation (1):

$$
\ln \left(\frac{\mathrm{d} a}{\mathrm{~d} t}\right)=\alpha+\frac{\beta}{R T} K_{\mathrm{I}}\left(\text { where } \alpha=\ln v_{0}+\ln a_{c}-\frac{E_{\mathrm{a}}}{R T}\right) .
$$

The value of $\alpha$ corresponds to the crack velocity at $K_{\mathrm{I}}=0$. The experimental scattering of this value is large. The stress

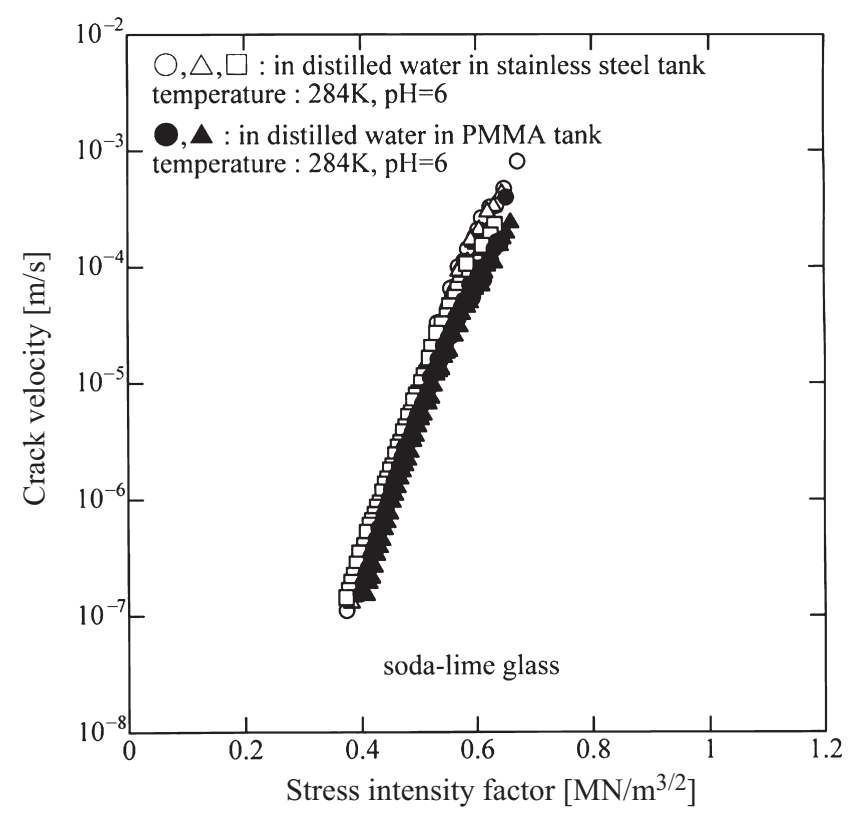

Fig. 6. $\quad K_{\mathrm{I}}-\mathrm{d} a / \mathrm{d} t$ relationships for soda-lime glass. Open and solid symbols represent data obtained from the apparatus shown in Figures $3 a$ and $3 b$, respectively.

intensity factor at $\mathrm{d} a / \mathrm{d} t=10^{-5}[\mathrm{~m} / \mathrm{s}], K_{\mathrm{I}}\left(10^{-5}\right)$, is listed in Tables 1 and 2 to provide a quantitative comparison of the stress intensity factor because the range of the crack velocity was $10^{-2}-10^{-8} \mathrm{~m} / \mathrm{s}$. Because the range of the stress intensity factor for Kumamoto andesite was $0.8-1.4 \mathrm{MN} / \mathrm{m}^{3 / 2}$, the crack velocity at $K_{\mathrm{I}}=1.1\left[\mathrm{MN} / \mathrm{m}^{3 / 2}\right], \mathrm{d} a / \mathrm{d} t(1.1)$, was listed in Table 1 to provide a quantitative comparison of the crack velocity. In the same way, $\mathrm{d} a / \mathrm{d} t(1.45)$ is listed in Table 2 to provide a quantitative comparison because the range of the stress intensity factor for Oshima granite was $1.2-1.7 \mathrm{MN} / \mathrm{m}^{3 / 2}$. The numbers given in these tables are the mean values and standard deviations of three specimens. The logarithmic average and standard deviation are provided for the crack velocity in Tables 1 and 2. 


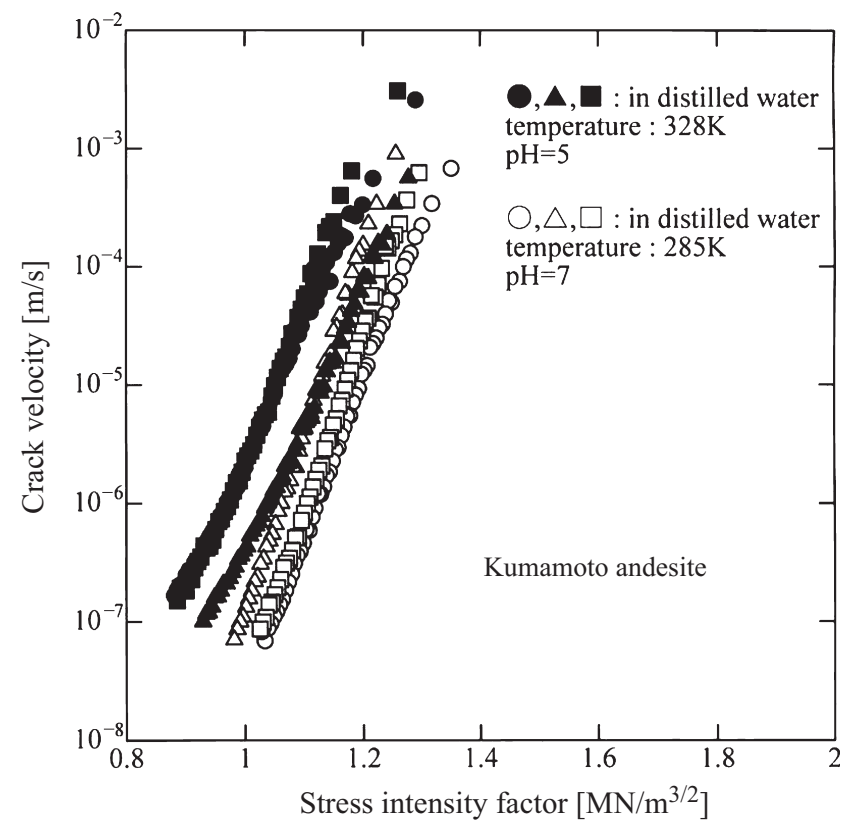

Fig. 7. $K_{\mathrm{I}}-\mathrm{d} a / \mathrm{d} t$ relationships for Kumamoto andesite at various temperatures.

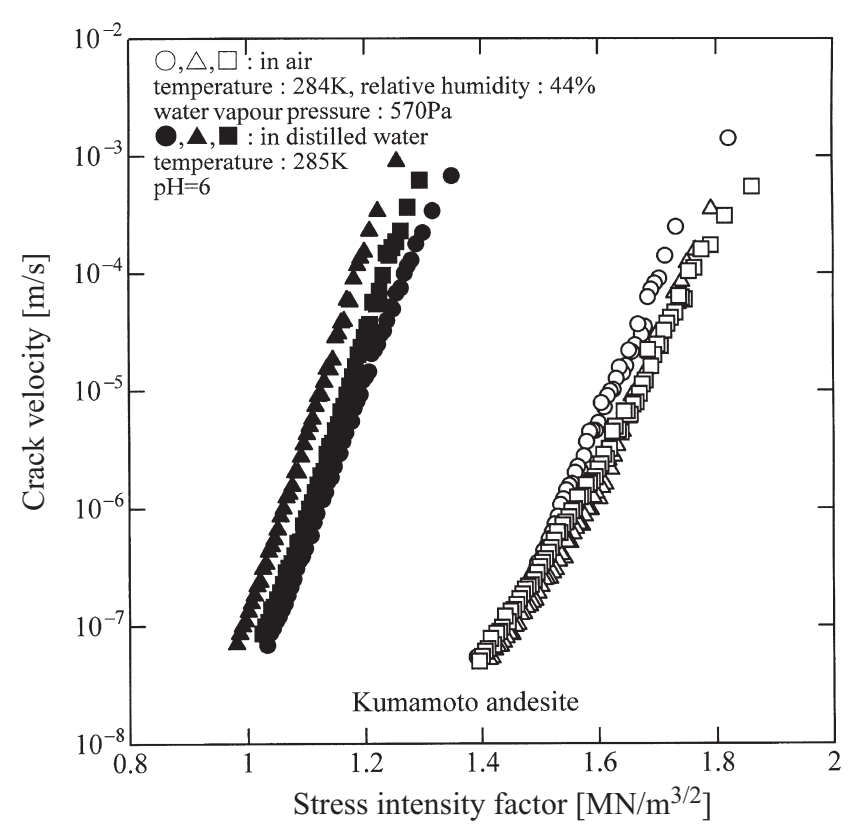

Fig. 8. $K_{\mathrm{I}}-\mathrm{d} a / \mathrm{d} t$ relationships for Kumamoto andesite in air and water.

As shown in Table $1, K_{\mathrm{I}}\left(10^{-5}\right)$ clearly decreased and $\mathrm{d} a / \mathrm{d} t(1.1)$ increased when the temperature was high. This indicates that the thermal activation process controls subcritical crack growth in rock in water. The values of the stress intensity factor and the crack velocity are recognised to be similar even though the bulk $\mathrm{pH}$ is different. It appears that the bulk $\mathrm{pH}$ has little effect on subcritical crack growth in rocks within the range of $\mathrm{pH}$ in this study.

The differences in the values of $\beta$ between Tables 1 and 2 are small. We considered $\beta$ to be a material constant.

\section{Discussion}

Some research has been conducted on the effect of water on subcritical crack growth in rocks. For example, Waza et al. (1980)

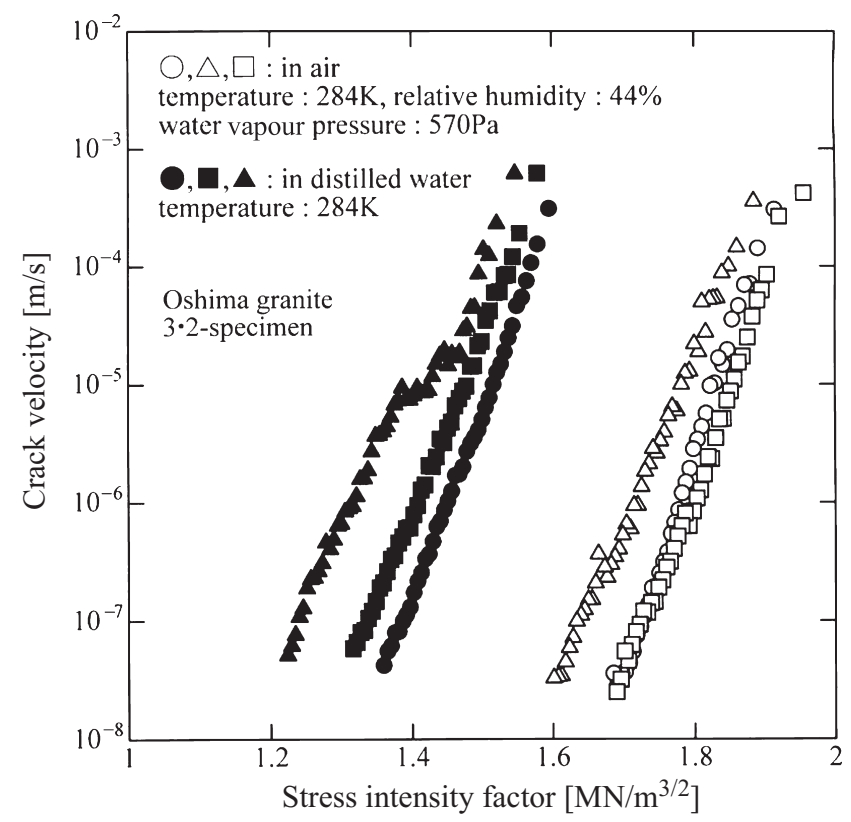

Fig. 9. $K_{\mathrm{I}}-\mathrm{d} a / \mathrm{d} t$ relationships for Oshima granite in air and water.

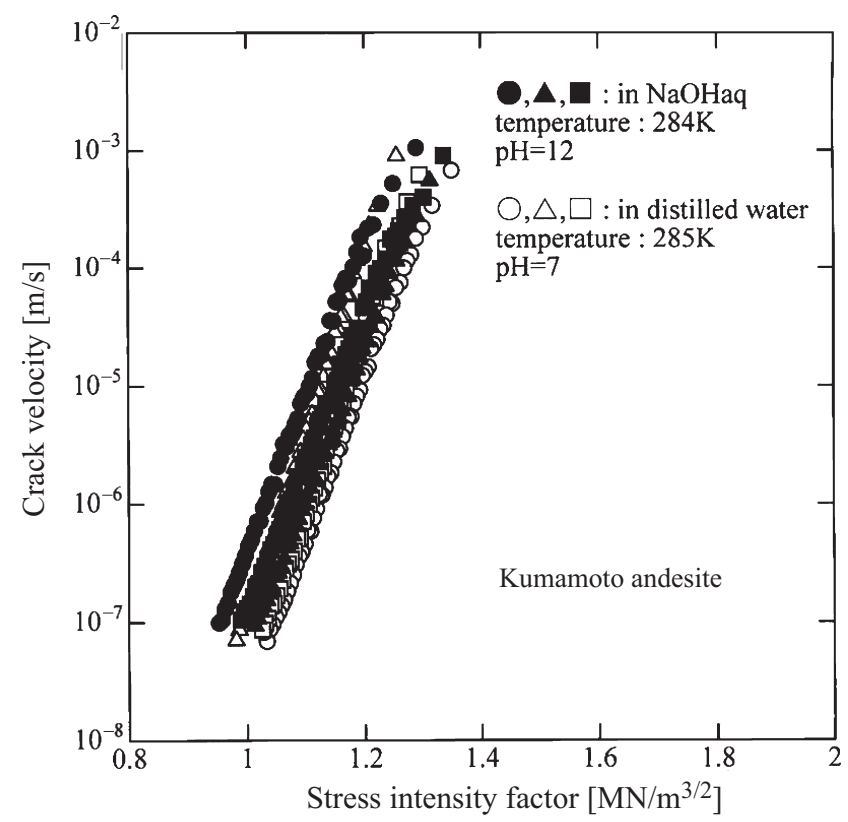

Fig. 10. $K_{\mathrm{I}}-\mathrm{d} a / \mathrm{d} t$ relationships for Kumamoto andesite under various $\mathrm{pH}$ conditions.

reported that the crack velocities for andesite and basalt in water were higher than those in air when tested with the DT constant load test (Kies and Clark, 1969). Although our experimental method was different, we observed the same tendency. These results are consistent with the observation that the subcritical crack growth in rocks is controlled by stress corrosion, and water is likely to be the corrosive agent (Atkinson, 1984).

Sano and Kudo (1992) investigated the $K_{\mathrm{I}}-\mathrm{d} a / \mathrm{d} t$ relationship in $\mathrm{NaOHaq}(\mathrm{pH}=11)$ for Oshima granite and reported that the crack velocity in $\mathrm{NaOHaq}$ was higher than that in distilled water by 1 or 2 orders of magnitude. Those results are shown in Figure 12, which was drawn by authors using the data of Sano 


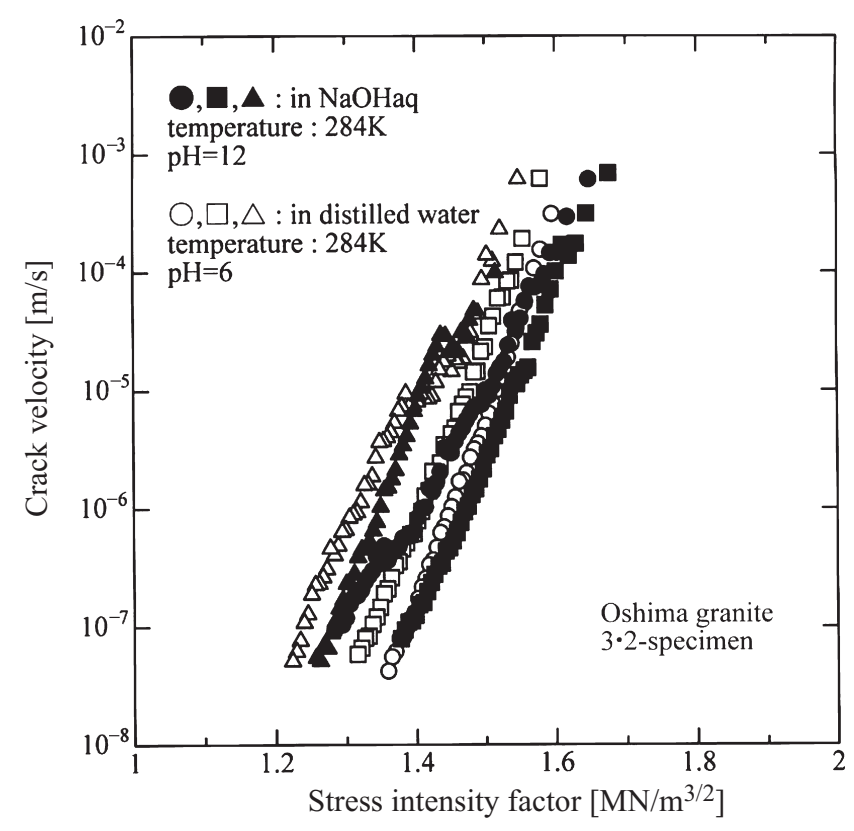

Fig. 11. $K_{\mathrm{I}}-\mathrm{d} a / \mathrm{d} t$ relationships for Oshima granite under various $\mathrm{pH}$ conditions.

and Kudo (1992), and do not agree with the results of our study. We must thus consider the possible reasons for the difference between our results and those of Sano and Kudo (1992).

In general, experimental results are subject to scattering due to the experimental apparatus and procedure, among other possible causes, which can be avoided by taking care to use the appropriate equipment and test procedures. We demonstrated that the reproducibility of our results for glass was quite high, as shown in Figure 6, indicating that our experimental apparatus was reliable and the procedure was appropriate.

The other source of result scattering is the heterogeneity of rock. In Oshima granite, the crack velocity data obtained using the DT test had some scattering even though the crack propagation direction and the crack opening direction were the same with each specimen. It thus seems wise to use multiple specimens when investigating rock properties. However, Sano and Kudo (1992) showed only one $K_{\mathrm{I}}-\mathrm{d} a / \mathrm{d} t$ relationship for each environment. Therefore, the possibility exists that a single specimen skewed their data, whereas our study used multiple specimens. Additionally, a definite dependency of the crack velocity on $\mathrm{pH}$ could not be observed. If DT tests had been conducted with only one specimen for each environment, a spread of 1 or 2 orders of magnitude of the crack velocity would have been observed as shown in Figure 13, which illustrates the same $K_{\mathrm{\Gamma}}-\mathrm{d} a / \mathrm{d} t$ relationships shown in Figure 11 . Because we used multiple specimens and considered the scattering of the data, the results in this study are most likely more reliable.

Based on our findings, we concluded that bulk $\mathrm{pH}$ has little effect on the crack growth in rock, which is consistent with the observations for soda-lime glass by Wiederhorn and Johnson (1973). Wiederhorn (1972) showed that the $\mathrm{pH}$ of a slurry made with water and finely ground soda-lime glass was around 12 , even though the $\mathrm{pH}$ of water was neutral. From other studies of glass, Wiederhorn (1978) suggested that the $\mathrm{pH}$ of the crack tip solution is highly dependent on the chemistry of the solid phase. The basic solution at the crack tip is formed with glass containing alkali through the following ion-exchange reaction:

$$
\mathrm{Na}^{+}(\text {glass })+\mathrm{H}_{2} \mathrm{O} \rightleftarrows \mathrm{H}^{+}(\text {glass })+\mathrm{Na}^{+} \mathrm{OH}^{-} .
$$

Charles (1958) proposed the following chemical reaction between the hydroxide ion and a silicon-oxygen network to explain the effect of $\mathrm{pH}$ on the crack growth rate as:

$$
\equiv \mathrm{Si}-\mathrm{O}-\mathrm{Si} \equiv+\mathrm{OH}^{-} \rightarrow \equiv \mathrm{Si}_{-} \mathrm{O}^{-}+\equiv \mathrm{Si}-\mathrm{OH} .
$$

Assuming that the state of the solution at the crack tip was equal to the ground glass-water slurries, Wiederhorn and Johnson (1973) reported that the $\mathrm{pH}$ at the crack tip of soda-lime glass could be $\sim 12$, even though the surrounding environment was water, and they concluded that the $\mathrm{pH}$ at the crack tip, rather than the bulk $\mathrm{pH}$, influenced the $K_{\mathrm{I}}-\mathrm{d} a / \mathrm{d} t$ relationship.

However, the bulk pH does affect subcritical crack growth in silica glass (Wiederhorn and Johnson, 1973) and synthetic quartz (Atkinson and Meredith, 1981) when the crack velocities are low. The crack velocity increased when the bulk $\mathrm{pH}$ was higher in both cases. The reasoning is as follows. Using direct measurements, the $\mathrm{pH}$ of slurries of silica glass was 4-5 for silica glass (Wiederhorn, 1972) and 6.5 for quartz (Atkinson and Meredith, 1981), based on the $\mathrm{pH}$ measurement of deionised water passing through a column of ground quartz. In both cases, the amount of the ground solid was much higher than that of water. If these are consistent with the $\mathrm{pH}$ of the crack tip solutions, the differences in the $\mathrm{pH}$ are large when the surrounding environment is a basic solution such as $\mathrm{NaOHaq}$. Diffusion of hydroxide ions from the bulk solution to the crack tip can occur in these cases, and the $\mathrm{pH}$ of the crack tip solutions could approach the bulk $\mathrm{pH}$ value when the crack velocity is low. Therefore, subcritical crack

Table 1. Summary of the results for Kumamoto andesite.

s.d., standard deviation

\begin{tabular}{lcccc}
\hline Condition & $\alpha$ & $\begin{array}{c}\beta \\
\left(\mathrm{m}^{5 / 2} / \mathrm{mol}\right)\end{array}$ & $\begin{array}{c}K_{\mathrm{I}}\left(10^{-5}\right) \\
\left(\mathrm{MN} / \mathrm{m}^{3 / 2}\right)\end{array}$ & $\begin{array}{c}\mathrm{d} a / \mathrm{d} t(1.1) \\
(\mathrm{m} / \mathrm{s})\end{array}$ \\
\hline In distilled water $328 \mathrm{~K}, \mathrm{pH}=5$ & $-43.9 \pm 2.2$ & $0.082 \pm 0.008$ & $1.08 \pm 0.05$ & $2.51 \times 10^{-5}\left(\mathrm{~s} . \mathrm{d} .: 3.63 \times 10^{0} \mathrm{in} \log \right)$ \\
In distilled water 285 K, $\mathrm{pH}=7$ & $-52.5 \pm 2.3$ & $0.083 \pm 0.006$ & $1.16 \pm 0.03$ & $1.07 \times 10^{-6}\left(\mathrm{~s} . \mathrm{d} .: 2.45 \times 10^{0} \mathrm{in} \log \right)$ \\
In NaOHaq 284 K, $\mathrm{pH}=12$ & $-45.0 \pm 1.4$ & $0.069 \pm 0.002$ & $1.14 \pm 0.04$ & $2.34 \times 10^{-6}\left(\mathrm{~s} . \mathrm{d} .: 2.75 \times 10^{0} \mathrm{in} \mathrm{log}\right)$ \\
\hline
\end{tabular}

Table 2. Summary of the results for Oshima granite.

\begin{tabular}{|c|c|c|c|c|}
\hline Condition & $\alpha$ & $\begin{array}{c}\beta \\
\left(\mathrm{m}^{5 / 2} / \mathrm{mol}\right)\end{array}$ & $\begin{array}{l}K_{\mathrm{I}}\left(10^{-5}\right) \\
\left(\mathrm{MN} / \mathrm{m}^{3 / 2}\right)\end{array}$ & $\begin{array}{c}\mathrm{d} a / \mathrm{d} t(1.45) \\
(\mathrm{m} / \mathrm{s})\end{array}$ \\
\hline In distilled water $284 \mathrm{~K}, \mathrm{pH}=6$ & $-58.4 \pm 10.8$ & $0.076 \pm 0.016$ & $1.46 \pm 0.05$ & $5.37 \times 10^{-6}\left(\right.$ s.d.: $4.57 \times 10^{0}$ in $\left.\log \right)$ \\
\hline In $\mathrm{NaOHaq} 284 \mathrm{~K}, \mathrm{pH}=12$ & $-55.8 \pm 8.4$ & $0.072 \pm 0.015$ & $1.45 \pm 0.07$ & $9.27 \times 10^{-6}$ (s.d.: $9.77 \times 10^{0}$ in $\left.\log \right)$ \\
\hline
\end{tabular}

s.d., standard deviation 


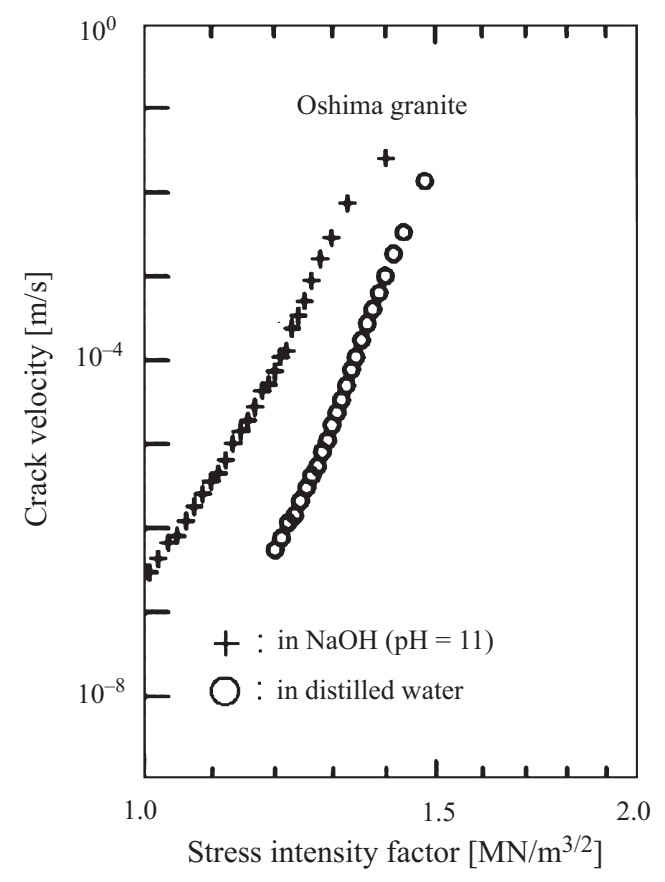

Fig. 12. $K_{\mathrm{I}}-\mathrm{d} a / \mathrm{d} t$ relationships for Oshima granite obtained by Sano and Kudo (1992). This figure was drawn by the authors using the data of Sano and Kudo.

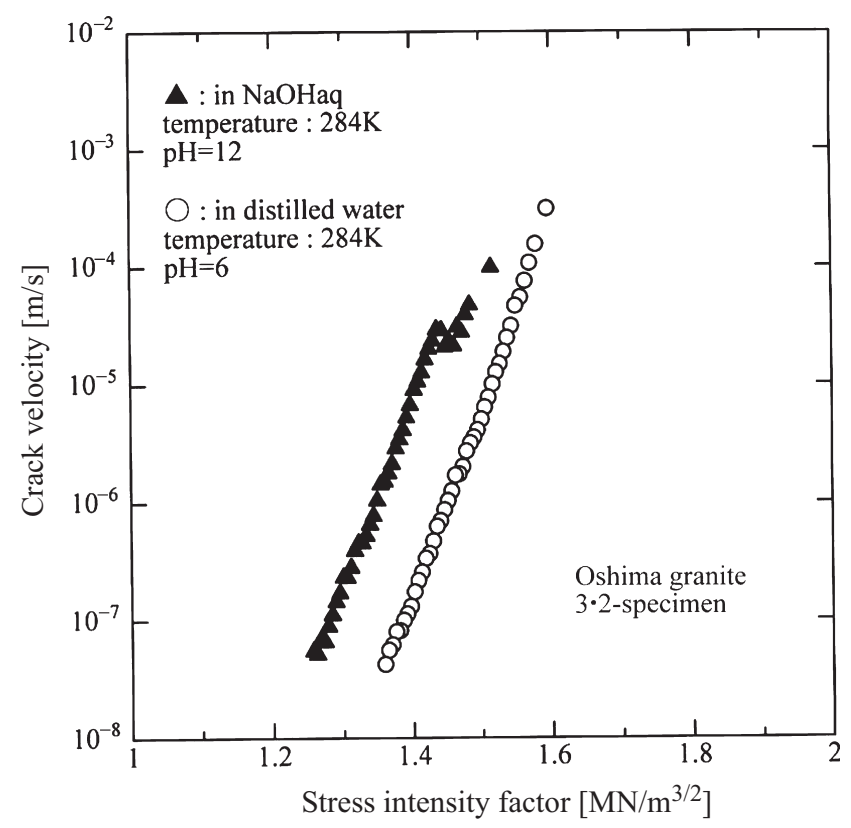

Fig. 13. $\quad K_{\mathrm{I}}-\mathrm{d} a / \mathrm{d} t$ relationships for Oshima granite selected from Figure 11 .

growth in silica glass and synthetic quartz is affected by the bulk $\mathrm{pH}$.

In the present study, the $\mathrm{pH}$ of distilled water that included the powders of andesite or granite was measured. At first, rock was ground into powders less than $50 \mu \mathrm{m}$ and mixed into distilled water. The distilled water with the rock powders was kept for 2 days at the temperature of $284 \mathrm{~K}$, and then the $\mathrm{pH}$ was measured. The results of the $\mathrm{pH}$ measurements for distilled water with ground Kumamoto andesite and Oshima granite (less than $50 \mu \mathrm{m}$ ) are shown in Figure 14, along with the amounts of the ground rock and distilled water. This illustrates that the $\mathrm{pH}$ increased and converged to 7-8 for Kumamoto andesite and to

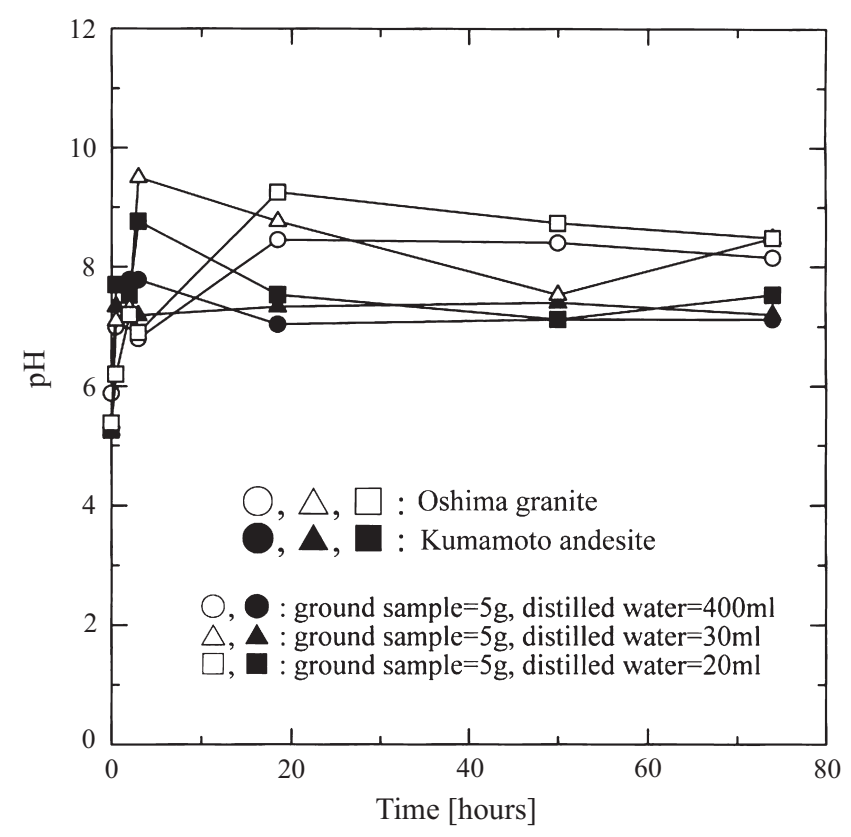

Fig. 14. Measured $\mathrm{pH}$ for distilled water with ground andesite and granite (less than $50 \mu \mathrm{m})$.

8-9 for Oshima granite, although the initial values of the $\mathrm{pH}$ were 5-6 in both cases. These $\mathrm{pH}$ increases might show that the $\mathrm{pH}$ at the crack tip in rock can also be greater than the $\mathrm{pH}$ of the bulk solution. Namely, Figure 14 indicates that the $\mathrm{pH}$ at the crack tip in these rocks can increase, even if the bulk environment is water. Becuase the surface area of the crack in rock is large and the amount of the crack tip solution is small, the actual ratio of the surface area to the crack tip solution should be much larger than those shown in Figure 14. Therefore, the $\mathrm{pH}$ of the crack tip solution can be higher than those shown in Figure 14. Therefore, the bulk pH might have little effect on subcritical crack growth in rock.

\section{Conclusion}

We investigated the subcritical crack growth in rocks in distilled water $(\mathrm{pH}=5-7)$ and in $\mathrm{NaOH}$ solution $(\mathrm{pH}=12)$ using the DT test. From measurements in distilled water, we showed that the crack velocity was higher when the temperature was higher, and much higher in water than in air. We demonstrated that the difference in the crack velocity and stress intensity factor were not significant even though the bulk pH changed. We concluded that the $\mathrm{pH}$ at the crack tip influences subcritical crack growth, and not the bulk $\mathrm{pH}$, which has little effect.

\section{Acknowledgment}

We appreciate the support of Research Fellowship of the Japan Society for the Promotion of Science for Young Scientists.

\section{References}

Anderson, O. L., and Grew, P. C., 1977, Stress corrosion theory of crack propagation with applications to geophysics: Reviews of Geophysics and Space Physics, 15, 77-104. doi: 10.1029/RG015i001p00077

Atkinson, B. K., 1984, Subcritical crack growth in geological materials: Journal of Geophysical Research, 89, 4077-4114. doi: 10.1029/ JB089iB06p04077

Atkinson, B. K., and Meredith, P. G., 1981, Stress corrosion cracking of quartz: a note on the influence of chemical environment: Tectonophysics, 77, T1-T11. doi: 10.1016/0040-1951(81)90157-8 
Charles, R. J., 1958, Static fatigue of glass I: Journal of Applied Physics, 29, 1549-1553. doi: 10.1063/1.1722991

Freiman, S. W., 1984, Effects of chemical environments on slow crack growth in glasses and ceramics: Journal of Geophysical Research, 89, 4072-4076. doi: 10.1029/JB089iB06p04072

Jeong, H. S., Kang, S. S., and Obara, Y., 2007, Influence of surrounding environments and strain rates on the strength of rocks subjected to uniaxial compression: International Journal of Rock Mechanics and Mining Sciences, 44, 321-331. doi: 10.1016/j.ijrmms.2006.07.009

Kies, J. A., and Clark, A. B. J., 1969, Fracture propagation rates and times to fail following proof stress in bulk glass: in Platt, P.L. (ed.), Fracture 1969: Chapman and Hall, pp. 483-491.

Kodama, N., Fujii, Y., and Ishijima, Y., 2003, The effect of temperature on the mechanical properties of Inada granite and Shirahama sandstone: Kyoto, Japan: Proceedings of The First Kyoto International Symposium on Underground Environment - Role of Geo-technology to the Underground Environment, pp. 193-200.

Kudo, Y., Hashimoto, K., Sano, O., and Nakagawa, K., 1987, Relation between physical anisotropy and microstructures of granitic rock in Japan: Montreal, Canada: Proceedings of 6th International Congress on Rock Mechanics, pp. 429-432.

Michalske, T. A., and Freiman, S. W., 1982, A molecular interpretation of stress corrosion in silica: Nature, 295, 511-512. doi: 10.1038/295511a0

Nara, Y., 2004, Study of subcritical crack growth in rock: Ph.D. Thesis, Hokkaido University (in Japanese).

Nara, Y., and Kaneko, K., 2005, Study of subcritical crack growth in andesite using the Double Torsion test: International Journal of Rock Mechanics and Mining Sciences, 42, 521-530. doi: 10.1016/j.ijrmms.2005.02.001

Nara, Y., and Kaneko, K., 2006, Sub-critical crack growth in anisotropic rock: International Journal of Rock Mechanics and Mining Sciences, 43, 437-453. doi: 10.1016/j.ijrmms.2005.07.008

Nara, Y., Koike, K., Yoneda, T., and Kaneko, K., 2006, Relation between subcritical crack growth behavior and crack path in granite: International Journal of Rock Mechanics and Mining Sciences, 43, 1256-1261. doi: 10.1016/j.ijrmms.2006.03.016

Peacock, S., McCann, C., Sothcott, J., and Astin, T. R., 1994, Seismic velocities in fractured rocks: an experimental verification of Hudson's theory: Geophysical Prospecting, 42, 27-80. doi: 10.1111/j.13652478.1994.tb00193.x
Pletka, B. J., Fuller, E. R., Jr, and Koepke, B. G., 1979, An evaluation of double-torsion testing - Experimental: ASTM Special Technical Publication, 678, 19-37.

Sano, O., and Kudo, Y., 1992, Relation of fracture resistance to fabric for granitic rocks: Pure and Applied Geophysics, 138, 657-677. doi: 10.1007/ BF00876343

Sano, O., Kudo, Y., and Mizuta, Y., 1992, Experimental determination of elastic constants of Oshima granite, Barre granite, and Chelmsford granite: Journal of Geophysical Research, 97, 3367-3379. doi: 10.1029/ 91JB02934

Trantina, G. G., 1977, Stress analysis of the Double-Torsion specimen: Journal of the American Ceramic Society, 60, 338-341. doi: 10.1111/ j.1151-2916.1977.tb15556.x

Waza, T., Kurita, K, and Mizutani, H., 1980, The effect of water on the subcritical crack growth in silicate rocks: Tectonophysics, 67, 25-34. doi: 10.1016/0040-1951(80)90162-6

Wiederhorn, S. M., 1972, A chemical interpretation of static fatigue: Journal of the American Ceramic Society, 55, 81-85. doi: 10.1111/j.11512916.1972.tb11215.x

Wiederhorn, S. M., 1978, Mechanisms of subcritical crack growth in glass: in Bradt, R.C., Hasselman, D.P.H. and Lange F.F. (eds.), Fracture Mechanics of Ceramics vol. 4: Chapman and Hall, pp. 549-580.

Wiederhorn, S. M., and Bolz, L. H., 1970, Stress corrosion and static fatigue of glass: Journal of the American Ceramic Society, 53, 543-548. doi: 10.1111/j.1151-2916.1970.tb15962.x

Wiederhorn, S. M., and Johnson, H., 1973, Effect of electrolyte $\mathrm{pH}$ on crack propagation in glass: Journal of the American Ceramic Society, 56, 192-197. doi: 10.1111/j.1151-2916.1973.tb12454.x

Williams, D. P., and Evans, A. G., 1973, A simple method for studying slow crack growth: Journal of Testing and Evaluation, 1, 264-270.

Manuscript received 20 December 2007; revised manuscript received 6 October 2008. 


\section{水溶液環境下における岩石のサブクリティカルき裂進展*}

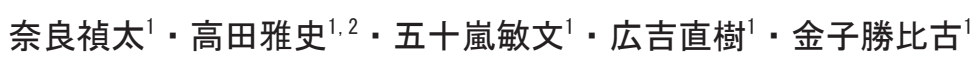

1 北海道大学大学院工学研究科

2 現在、日揮 (株)

要 旨： 低速で起こるき裂進展現象であるサブクリティカルき裂進展は、岩石の時間依存性の破壊挙動の重要な要素プロ セスである。本研究では、岩石のサブクリティカルき裂進展測定を、蒸留水中（ $\mathrm{pH}=5 \sim 7 ）$ および水酸化ナトリウム水溶液中 $(\mathrm{pH}=12)$ で行い、き裂進展に及ぼす $\mathrm{pH}$ の影響を調べた。さらに、水溶液環境下で得られた結果と大気中で得られた結果の 比較を行った。岩石試料として、安山岩と花崗岩を用いた。試験法としてダブルトーション試験法を用い、き裂進展速度と応 力拡大係数の関係を求めた。また、全ての試験は、周辺環境の温度を制御した条件下で行った。試験より、水中におけるき裂 進展速度は、大気中でのものよりも大きくなった。これは、他の研究における結果と一致する傾向である。一方、水酸化ナ卜 リウム水溶液中で得られた結果を蒸留水中で得られた結果と比較したところ、周辺環境の $\mathrm{pH}$ が異なるにも係わらず、き裂進 展速度に明確な変化は認められなかった。この結果は、従来提唱されてきた、周辺環境中の水酸化物イオンが岩石のサブクリ ティカルき裂進展を促進するという考えとは異なるものである。本研究の結果より、き裂先端近傍における $\mathrm{pH}$ が岩石のサブ クリティカルき裂進展に影響し、周辺環境の $\mathrm{pH}$ が及ぼす影響は小さいものと考えられる。

キーワード : サブクリティカルき裂進展, ダブルトーション試験法, 岩石, 温度, 水溶液環境

*一部を第 19 回ASEG Geophysical Conference \& Exhibition（2007）にて発表

\section{수성환경에서 암석 내의 임계하 균열성장 연구*}

Yoshitaka Nara ${ }^{1}$, Masafumi Takada ${ }^{1,2}$, Toshifumi Igarashi ${ }^{1}$, Naoki Hiroyoshi $^{1}$, Katsuhiko Kaneko ${ }^{1}$

1 홋카이도대학 공학대학원

2 Presently, Nikki Corp.

요 약: 임계하 균열성장(subcritical crack growth)은 암석 내에서 오랜 시간 동안 일어나는 균열시스템 발달의 주된 원인으로 그 중요성이 매우 크다. 본 연구에서는 증류수 $(\mathrm{pH}=5-7)$ 와 수산화나트륨 $(\mathrm{NaOHaq}, \mathrm{pH}=12)$ 용액으로 포화된 암석과 건조암석에서의 임계하 균열성장에 대해 고찰하였다. 아울러 공극유체의 수소이온농도 $(\mathrm{pH})$ 의 영향도 함께 살펴보았으며, 안산암과 화강암이 연구에 사용되었다. 연구방법은 온도가 조절된 환경에서 이중-비틀림 실험(double-torsion test)을 실시하여 균열성장속도와 응력확장계수와의 상관관계를 파악하였다. 연구의 결과 수성환경에서 균열성장속도가 건조한 경우보다 크게 나타났으며, 이는 기존 연구에서 물이 첨가되었을 때 균열성장속도가 뺄라지는 결과와 잘 일치한다. 증류수와 수산화나트륨 사이의 결과에서는 수소이온농도의 차이에도 불구하고 균열성장속도의 차이가 나타나지 않았으며 이는 수산화이온이 균열성장을 가속한다는 기존의 결과와는 차이를 보였다. 따라서 균열의 첨단부(crack-tip)에서의 수소이온농도의 차이는 균열의 성장에 영향을 미치지만, 공극유체의 전체적인 수소이온농도(bulk $\mathrm{pH})$ 의 영향은 매우 적다는 결론을 얻을 수 있었다.

주요어 : 수성환경, 이중-비틀림 실험, 암석, 임계하 균열성장, 온도

*2007 년 11 월 제 19 차 ASEG 지구물리학회에서 발표 